\title{
Editorial Issue 1 Volume 3, 2011
}

\author{
Maurits W. Ertsen • Heather J. Hoag
}

Received: 21 March 2011/Accepted: 21 March 2011/Published online: 3 April 2011

(C) The Author(s) 2011. This article is published with open access at Springerlink.com

2011 promises to be an exciting year for Water History. Since our inception in 2009, we have produced two issues a year. With interest in the journal and field of water studies continuing to grow, we plan to publish three issues this year.

This issue continues our journey across space (northern Spain, Finland, South Africa, and the American Southwest) and time (12th century to the present). While the articles employ a range of approaches, methods, and sources, they all show the value of historicizing current debates on water management. As politicians, economists, water managers, and users debate the best way to address issues of equitable and effective distribution, economic and environmental costs, and increasing demands, drawing upon past experience is more important than ever.

The opening article by Christopher Gerrard examines technologies of water capture, storage, and distribution in northeastern Spain beginning in the Middle Ages. Gerrard uses both contemporary documents and archaeological fieldwork to explore allocation and administration of water rights in the region. After the 12th century, new patterns of land ownership and the Christian political administration influenced irrigation practice in the region. Gerrard shows that although irrigators continued to make routine decisions about their water system, they were no longer self-determining communities.

The contribution of Harri Mäki, Petri Juuti, and Rikka Rajala uses a comparative framework to historicize debates about water privatization in the cities of Tampere, Finland and Johannesburg, South Africa. By examining the similarities and differences in the construction of private waterworks by Wilhelm von Nottbeck (Tampere) and Sammy Marks (Johannesburg), the authors argue for the role of municipal governments in decisions about water supply. While the authors see a role for private capital, municipal oversight is needed to protect the public interest.

Finally, April Summitt takes us to the American Southwest where contestation over the use of the Colorado River continues. Summitt analyzes debates over the reallocation water

\footnotetext{
M. W. Ertsen $(\bowtie) \cdot$ H. J. Hoag

Water Resources/Water Management group, Department of Civil Engineering and Geosciences, Delft University of Technology, P. O. Box 5048, 2600 GA Delft, The Netherlands

e-mail: m.w.ertsen@tudelft.nl

URL: http://www.wrm.tudelft.nl
} 
in light of the region's continuing water shortages and increased population. She argues for a "middle ground between free markets and public trusts." Her article reminds of the continuing power of rivers to shape life in arid regions.

Open Access This article is distributed under the terms of the Creative Commons Attribution Noncommercial License which permits any noncommercial use, distribution, and reproduction in any medium, provided the original author(s) and source are credited. 